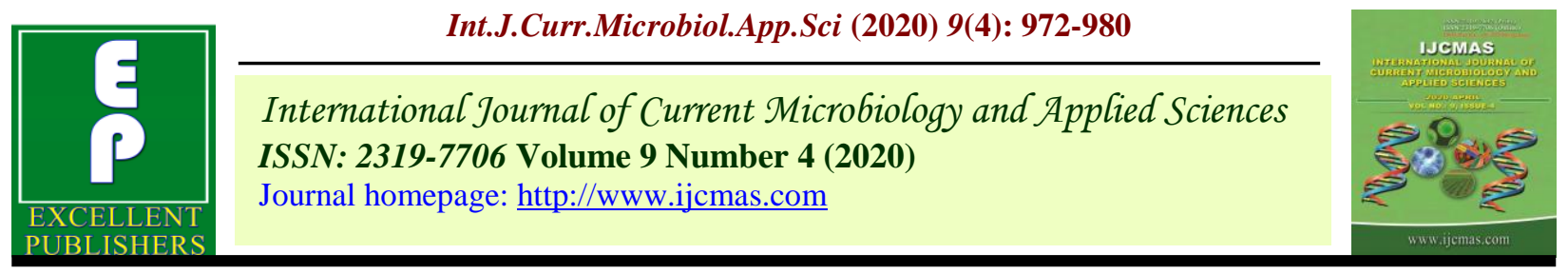

Original Research Article

https://doi.org/10.20546/ijcmas.2020.904.116

\title{
Small Scale Protected Cultivation for Off-season Vegetables: A Promising Option for Terai Farmers towards Income Generation
}

\author{
Soumen Maitra, Biplab Mitra, Rupak Sarkar*, Ranjit Chatterjee, \\ Surajit Khalko and Om Prakash Chaturvedi
}

Uttar Banga Krishi Viswavidyalaya, Pundibari, Cooch Behar, West Bengal-736165, India

*Corresponding author

\section{A B S T R A C T}

To evaluate the prospect of small-scale protected cultivation unit in homestead areas for growing off-season vegetables, low-cost bamboo made structures were constructed at Dhalaguri and Uttar Chokowakheti villages in the sub-Himalayan

Keywords

Poly-house,

Off-season,

Vegetables,

Soil moisture

Article Info

Accepted:

10 March 2020

Available Online:

10 April 2020 Terai region of West Bengal, India. Five crops, namely, cucumber, capsicum, coriander leaf, spinach beet and cauliflower were grown in different seasons during the period 2016-17. Results indicated the feasibility of protected cultivation for off season vegetable crops as a remunerative agro-enterprise with a high Benefit-Cost $(\mathrm{B}: \mathrm{C})$ ratio. The maximum and minimum $\mathrm{B}: \mathrm{C}$ ratio were 10.58 for off-season coriander leaf and 1.62 for off-season cucumber. The pest and disease problems in the poly-house crops were minimal. The major part of crop water requirement could be met from the residual soil moisture owing to low evaporation rate from the cladded and shaded poly-houses. Crops like off-season cauliflower could be grown without any supplemental irrigation. The farmers' response towards adoption of low-cost, small-scale protected cultivation technique was encouraging. The demonstrated technology could be a source of additional livelihood generation for the small, marginal and women farmers of the region.

\section{Introduction}

Crop response to the environment is the ultimate decisive factor towards a quality harvest and hence simulation of an ideal microclimate is one of the essential prerequisites of modern horticulture coupled with judicious application of agro-inputs to get higher quantum of healthy product per unit area through an environment safe sustainable approach leading to manifold return. Here lies the prospect of protected cultivation i.e. growing crops inside artificially constructed structures for favourable microclimate simulation.

Besides this, protected cultivation may also provide advantages like, year round cultivation, off-season cultivation, improvement in quality of produce 
(Kuswardhani et al., 2014), increase in yield per unit area (Negi et al., 2013), protection of crops from vagaries of climatic conditions such as heavy precipitation, chilling (Mishra et al., 2010), scorching etc., judicious application of space and agro-inputs, reduced use of water, production of seedlings for offseason cultivation, thereby realizing manifold return on investment (Singh and Sirohi, 2006).

Almost every country in the world is producing greenhouse crops to get quality production at higher magnitude per unit of land area. The difference between the principle of protected cultivation of the temperate world and the tropical world is lying in the fact that protected houses in temperate region target to step up the temperature but in the tropical and subtropical regions the main objective is to lower down the temperature and that's why the techniques differ between regions.

Upto the Second World War, glass was the predominating cladding material but with the advent of polyethylene as cladding material, the technique spread from the developed world to the developing countries (Maitra and De, 2016).

In India the concept has become popular amongst the farmers quite recently. Singh (2014) reported that an area of 40,000 ha is presently under protected cultivation of horticultural crops in India. Spehia (2015) indicated that out of $1,70,000$ ha of vegetable farming, an area of 223.18 ha was under greenhouse cultivation in Himachal Pradesh, India.

Effective water management strategies are major impetus which can be achieved by providing drip irrigation system in the protected structures. Singh and Hasan (2011) recommended zero energy naturally ventilated greenhouses for high value vegetable cultivation which can be equipped with low-pressure drip irrigation system to make them energy efficient eco-friendly model.

Construction of state of the art protected structures is costly and requires large initial investment by the farmers. This often restricts small and marginal farmers of India to adopt and harvest the benefits of protected cultivation.

But, such farmer groups are major and potential growers of a number of horticultural crops. Keeping this limitation in view, in the present study the scope of using small bamboo frame protected structures in homestead areas for protecting the crops from excessive precipitation, solar radiation, heat and cold were investigated. Simple polyhouse farming techniques were used so that small, marginal as well as women farmers could easily manage their poly-houses themselves.

The poly-houses were equipped with lowpressure drip irrigation systems for optimum and efficient water application to the crops. Perceiving the relative prospects of protected cultivation in the region, four low cost, bamboo made protected structures were constructed in two villages of West Bengal, India, namely, Dhalaguri and Uttar Chokowakheti.

The crops like cucumber, capsicum, coriander leaf, spinach beet and cauliflower were grown during off-seasons to study their feasibility and performance. This research trial was monitored and supported by the Australian Centre for International Agricultural Research (ACIAR) sponsored project 'Improving water use for dry season agriculture by marginal and tenant farmers in the Eastern Gangetic Plains'. 


\section{Materials and Methods}

\section{Study area}

The villages, namely, Dhalaguri and Uttar Chokowakheti are situated at the Ambari Gram Panchayat, Block II of Cooch Behar district and Uttar Chokowakheti Gram Panchayat, Block I of Alipurduar district, respectively, in the sub-Himalayan Terai region of West Bengal, India. The main characteristics of these two villages are heavy annual precipitation (2200-2500 $\mathrm{mm}$ ) in rainy season followed by a comparatively dry and prolonged winter season. The rainy season is characterized by much higher relative humidity than the winter season. Usually rainfall is minimal to nil during the winter months. The demography of both the villages is dominated by economically weak low caste population. Agriculture is the main source of livelihood in Dhalaguri whereas in Uttar Chokowakheti the livelihoods mostly revolve around natural forest resources with some seasonal practice of agriculture. The average farmers are mostly marginal with low operational land holding size ( $0.8 \mathrm{ha})$ and tenants working as agricultural labourer. Due to limited irrigation infrastructure in both the villages, dry season winter crops are not cultivated extensively.

\section{Protected structures}

Two numbers of poly-houses, each having dimensions of $12 \mathrm{~m} \times 4 \mathrm{~m}\left(48 \mathrm{~m}^{2}\right)$, were constructed in each of the two villages. The height of the poly-houses was $3 \mathrm{~m}$ at the centre. The structure of the poly-houses was made of bamboo poles fitted with nut and bolt. UV stabilized polyethylene sheet of 200 micron thickness was used as cladding material. Aluminium channels were fixed on bamboo poles for attaching the polyethylene sheet using metal springs. Above the polyethylene sheet $50 \%$ agro-shade net was used as shading material. The poly-houses were equipped with drip irrigation facility from an overhead tank having an effective head of about $4 \mathrm{~m}$. Four rows of drip irrigation laterals with 20 emitters per lateral were fitted to the main line. The nominal discharge of the drip emitters used was $2 \mathrm{lit} / \mathrm{h}$. The flow to individual laterals was controlled through inlet valves. The capacity of the overhead tank was 1000 lit. A 0.25 HP electric pump was used to lift the water to the tank either from surface or groundwater source. Being small sized structures the polyhouses could be accommodated easily in the homestead areas which made it highly feasible for the women farmers to manage the crops. The cost involvement for such a bamboo made protected structure of $4 \mathrm{~m}$ (width) $\times 12 \mathrm{~m}$ (length) $\times 3 \mathrm{~m}$ (central height) is presented in Table 1 .

\section{Results and Discussion}

\section{Crop production in poly-houses}

The choice of the crops to be cultivated in the poly-houses were decided considering the factors like crop feasibility, climate, potential yield, off-season market demand and acceptability, crop economic return, and farmers' skill and crop preference. Considering above mentioned factors and based on a participatory approach with the local farmers, the crops like cucumber, capsicum, cauliflower, coriander leaf and spinach beet were selected for off-season production in the poly-houses of the two villages during the period 20016-17. Local market survey indicated that these vegetable crops have high demand and market price during the off-season. Due to climatic limitations these crops are not feasible for open field cultivation. Therefore, it was presumed that off-season cultivation of these vegetable crops could be highly remunerative to the small and marginal farming community 
of the region. The cropping sequences of different crops cultivated in the poly-houses are enumerated in Table 2. The cultivars and time of planting of the selected vegetable crops are presented in Table 3.

In the research trial conducted the target groups of farmers were marginal, tenant and women farmers of the region. Therefore, it was critical to provide skill development hands-on trainings to the farmers on maintenance of protected structures, operation of drip irrigation system, water management of crops, raising of seedling, and soil nutrient and crop management practices in polyhouses.

Crop protection advices were also provided to the farmers through field demonstration and technical trainings. Close monitoring and farmers' awareness on crop management was key to success as the off-season vegetable crops are highly sensitive. The relevant crop inputs, supplemental water application and cost of cultivation are given in Table 4 .

\section{Production economics and water management}

The crop production and crop economic data were collected for all the crops cultivated in the poly-houses in different seasons. Production economics were analysed to estimate benefit cost ratio (B:C ratio) for all the crops (Table 5). Supplemental irrigation was provided to the crops through the installed drip irrigation systems. The soil moisture level of the poly-houses was regularly monitored using a TDR soil moisture meter. Irrigation was scheduled based on moisture extraction pattern of the respective crops. The volume of irrigation water applied to different crops and actual percent of crop water requirement supplied through supplemental irrigation are enumerated in Table 6.
Amongst the five crops cultivated in the polyhouses, capsicum was the longest duration crop (6 months) and the other crops were harvested within 3 months. The short duration crops like spinach beet and coriander leaf had the advantage that in off-season two successive crops could be grown within a span of five months. These two crops were found to be highly remunerative to the farmers. Capsicum was found to be the highest nutrient demanding crop and therefore the cost of production was higher compared to the other crops (Tables 4 and 5). The cost of production was found to be least for coriander leaf (Rs. 248.78/-) and maximum for capsicum (Rs. 908.16/-).

In spite of this, the maximum net return was realized from capsicum crop (Rs. 4691.84/-) as the crop yield was good and market price of off-season capsicum was also high (Table $5)$. The minimum return was obtained from cucumber crop (Rs. 183.10/-) as the crop was already abundant in the market even in the off-season and thus price was not significantly high. Kaddi et al., (2014) also reported a lower $\mathrm{B}: \mathrm{C}$ ratio in naturally ventilated poly-house grown cucumber than open field cultivation. The crop economic data revealed that the $\mathrm{B}: \mathrm{C}$ ratio was maximum for coriander leaf (10.58) amongst the short duration crops.

For capsicum the $\mathrm{B}: \mathrm{C}$ ratio was also quite high (6.17) due to higher market prices owing to low local supply from conventional agriculture during off-season. Dhaliwal et al., (2017) reported an early as well as higher yield in poly-house grown bell pepper or capsicum. Similar observation was also made by Lal et al., (2016) for coriander leaf. Early cauliflower grown in the poly-houses were of good quality and had decent demand in market. The crop was found to be highly profitable for the farmers. Agrawal et al., (2003) also reported the profitability of early 
cauliflower under protected situation in Chhattisgarh region of India. It was also evident that in off-season production of vegetable crops the pest and disease infestation was minimal and no chemical or pesticides were required to be applied to the crops.

Table.1 Cost of construction of one poly-house $(12 \mathrm{~m} \times 4 \mathrm{~m})$

\begin{tabular}{|c|c|c|c|c|}
\hline $\begin{array}{l}\text { Sl. } \\
\text { No. }\end{array}$ & Item & Quantity & Rate & Amount (Rs.) \\
\hline 1. & Bamboo & 40 numbers & Rs. $80 /$ piece & Rs. 3200/- \\
\hline 2 & $\begin{array}{l}\text { UV-stabilized } \\
\text { polyethylene sheet of } \\
200 \text { micron thickness }\end{array}$ & $162 \mathrm{~m}^{2}$ & Rs. $65 / \mathrm{m}^{2}$ & Rs. 10530/- \\
\hline 3 & $\begin{array}{l}\text { Nails } \\
\text { Spring } \\
\text { Channel } \\
\text { Nylon Rope } \\
\text { Ribbon } \\
\text { Frame of Door }\end{array}$ & $\begin{array}{l}2 \mathrm{~kg} \\
100 \text { pieces } \\
100 \mathrm{~m} \\
1 \mathrm{~kg} \\
100 \mathrm{~m} \\
1 \text { piece }\end{array}$ & $\begin{array}{l}\text { Rs. } 80 / \mathrm{kg} \\
\text { Rs. } 2.5 / \text { piece } \\
\text { Rs. } 3 / \mathrm{m} \\
\text { Rs. } 80 / \mathrm{kg} \\
\text { Rs. } 2 / \mathrm{m} \\
\text { Rs.100/piece }\end{array}$ & $\begin{array}{l}\text { Rs.160/- } \\
\text { Rs.250/- } \\
\text { Rs.300 } \\
\text { Rs. } 80 /- \\
\text { Rs.200/- } \\
\text { Rs.100/- }\end{array}$ \\
\hline 4 & 50\% Agro-shade Net & $100 \mathrm{~m}^{2}$ & Rs. $20 / \mathrm{m}^{2}$ & Rs.2000/- \\
\hline 5 & Wages & 2 man-days for 2 days & Rs.250/man-day & Rs.1000/- \\
\hline \multirow[t]{2}{*}{6} & Miscellaneous cost & - & - & Rs.400/- \\
\hline & & & Grand Total & Rs.18220/- \\
\hline
\end{tabular}

Table.2 Cropping sequences in the poly-houses of (2016-17)

\begin{tabular}{|c|c|c|c|}
\hline Production Month & $\begin{array}{c}\text { Crops Cultivated } \\
\text { Poly-house - } 1\end{array}$ & Production Month & $\begin{array}{c}\text { Crops Cultivated } \\
\text { Poly-house - } 2\end{array}$ \\
\hline \multicolumn{4}{|l|}{ Village: Dhalaguri } \\
\hline Dec, 16 - Jun, 17 & Off-season capsicum & Dec, 16 -Apr, 17 & Cucumber \\
\hline Jul, 17 - Nov, 17 & Cauliflower & May, 17 - Aug, 17 & $\begin{array}{l}\text { Off-season coriander leaf } \\
\text { and off-season spinach } \\
\text { beet }\end{array}$ \\
\hline & & Sept, 17 - Nov, 17 & Cauliflower \\
\hline \multicolumn{4}{|c|}{ Village: Uttar Chokowakheti } \\
\hline Jun, 17 - Sept, 17 & $\begin{array}{l}\text { Off-season coriander } \\
\text { leaf and off-season } \\
\text { spinach beet }\end{array}$ & Jun, 17 - Sept, 17 & $\begin{array}{l}\text { Off-season coriander leaf } \\
\text { and off-season spinach } \\
\text { beet }\end{array}$ \\
\hline Sept,17 - Nov, 17 & Cauliflower & Sept, $17-$ Nov, 17 & Cauliflower \\
\hline
\end{tabular}


Table.3 The cultivars of different vegetable crops and seed requirement and cost

\begin{tabular}{|c|c|c|c|c|c|c|c|}
\hline $\begin{array}{l}\text { Sl. } \\
\text { no. }\end{array}$ & Crop & Botanical name & Family & $\begin{array}{l}\text { Unit } \\
\text { Size } \\
\left(\mathbf{m}^{2}\right)\end{array}$ & Variety & $\begin{array}{c}\text { Seed } \\
\text { Required } \\
\text { (g) }\end{array}$ & $\begin{array}{l}\text { Cost of } \\
\text { Seed } \\
\text { (Rs.) }\end{array}$ \\
\hline 1. & Cucumber & Cucumis sativus & Cucurbitaceae & 24 & Malini & 10 & $220 /-$ \\
\hline 2. & Capsicum & $\begin{array}{l}\text { Capsicum } \\
\text { annuum } \\
\text { grossum }\end{array} \quad$ var. & Solanaceae & 48 & Mekong F1 & 5 & $400 /-$ \\
\hline 3. & $\begin{array}{l}\text { Coriander } \\
\text { leaf }\end{array}$ & $\begin{array}{l}\text { Coriandrum } \\
\text { sativum }\end{array}$ & Umbelliferae & 24 & Local & 500 & $150 /-$ \\
\hline 4. & $\begin{array}{l}\text { Spinach } \\
\text { Beet }\end{array}$ & $\begin{array}{l}\text { Beta vulgaris } \\
\text { var. bengalensis }\end{array}$ & Chenopodiaceae & 24 & Local & 500 & 240/- \\
\hline 5. & Cauliflower & $\begin{array}{l}\text { Brassica } \\
\text { oleracea } \\
\text { botrytis }\end{array}$ & Cruciferae & 48 & $\begin{array}{c}\text { Dawn }-175 \\
\text { and } \\
\text { SV4051AC }\end{array}$ & 5 & 200/- \\
\hline
\end{tabular}

Table.4 Irrigation and nutrient requirements to crops cultivated in the poly-houses

\begin{tabular}{|c|c|c|c|c|c|}
\hline Crop & $\begin{array}{l}\text { Manures and fertilizer } \\
\text { application }\end{array}$ & $\begin{array}{l}\text { Cost of } \\
\text { manure } \\
\text { and } \\
\text { fertilizer }\end{array}$ & $\begin{array}{l}\text { Theoretical } \\
\text { water } \\
\text { requirement } \\
\text { in open field }\end{array}$ & $\begin{array}{l}\text { Water } \\
\text { applied } \\
\text { through } \\
\text { drip (lit) }\end{array}$ & $\begin{array}{c}\text { Cost of } \\
\text { water } \\
\text { application }\end{array}$ \\
\hline Cucumber & $\begin{array}{l}\text { Vermicompost }-10.5 \mathrm{~kg} \\
\text { Urea }-0.70 \mathrm{~kg} \mathrm{SSP}-1.40 \mathrm{~kg} \\
\text { MOP }-0.35 \mathrm{~kg}\end{array}$ & Rs. 62.16/- & 20 ha-cm & 686.40 & Rs. 8.24/- \\
\hline Capsicum & $\begin{array}{l}\text { Vermicompost }-60 \mathrm{~kg} \\
\text { Urea }-5 \mathrm{~kg} \\
\mathrm{SSP}-20 \mathrm{~kg} \\
\text { MOP }-3 \mathrm{~kg} \\
\text { 19:19:19(liquid fertilizer) }-100 \mathrm{~g}\end{array}$ & $\begin{array}{c}\text { Rs. } \\
\text { 486.20/- }\end{array}$ & $25-40$ ha-cm & 1830.20 & Rs. 21.96/- \\
\hline $\begin{array}{l}\text { Coriander } \\
\text { leaf }\end{array}$ & Vermicompost - $24 \mathrm{~kg}$ & Rs. 96/- & 5-10 ha-cm & 232.00 & Rs. $2.78 /-$ \\
\hline Spinach beet & Vermicompost - $24 \mathrm{~kg}$ & Rs. 96/- & 5-10 ha-cm & 225.60 & Rs. 2.71/- \\
\hline Cauliflower & Vermicompost $-8.50 \mathrm{~kg}$ & Rs. 34/- & $15-30 \mathrm{ha}-\mathrm{cm}$ & 0.00 & Rs. 0.00/- \\
\hline
\end{tabular}


Table.5 Production economics of different crops cultivated in the poly-houses

\begin{tabular}{|l|c|l|c|l|c|}
\hline \multicolumn{1}{|c|}{ Crop } & $\begin{array}{c}\text { Cost of } \\
\text { production } \\
\text { (Rs.) }\end{array}$ & \multicolumn{1}{|c|}{ Yield } & $\begin{array}{c}\text { Selling } \\
\text { price } \\
\text { (Rs.) }\end{array}$ & \multicolumn{1}{|c|}{$\begin{array}{c}\text { Net return } \\
\text { (Rs.) }\end{array}$} & $\begin{array}{c}\text { B:C Ratio } \\
\text { (Gross return/ } \\
\text { Total Cost) }\end{array}$ \\
\hline Cucumber & $296.90 /-$ & $40 \mathrm{~kg}$ & $480 /-$ & $\begin{array}{l}183.10 /- \\
\text { (in3 months) }\end{array}$ & 1.62 \\
\hline Capsicum & $908.16 /-$ & $100 \mathrm{~kg}$ & $5600 /-$ & $\begin{array}{l}4691.84 /- \\
\text { (in } 6 \text { months) }\end{array}$ & 6.17 \\
\hline Coriander leaf & $248.78 /-$ & $9.6 \mathrm{~kg}$ & $2880 /-$ & $\begin{array}{l}2631.22 /- \\
\text { (in } 2.5 \text { months) }\end{array}$ & 10.58 \\
\hline Spinach beet & $338.71 /-$ & $66 \mathrm{~kg}$ & $2310 /-$ & $\begin{array}{l}1971.29 /- \\
\text { (in } 2.5 \mathrm{months})\end{array}$ & 6.82 \\
\hline Cauliflower & $314.00 /-$ & $68 \mathrm{~kg}$ & $2040 /-$ & $\begin{array}{l}1726.00 /- \\
\text { (in } 2.5 \text { months })\end{array}$ & 6.50 \\
\hline
\end{tabular}

Table.6 Comparative use of water in protected cultivation of vegetables in 2016-17

\begin{tabular}{|l|c|c|c|c|c|}
\hline \multicolumn{1}{|c|}{ Crop } & $\begin{array}{c}\text { Standard crop } \\
\text { water } \\
\text { requirement } \\
\text { (ha-cm) }\end{array}$ & $\begin{array}{c}\text { Plot } \\
\text { area } \\
\mathbf{( m}^{\mathbf{2}} \mathbf{)}\end{array}$ & $\begin{array}{c}\text { Volume of } \\
\text { water } \\
\text { required by } \\
\text { the crop (lit) }\end{array}$ & $\begin{array}{c}\text { Irrigation } \\
\text { water applied } \\
\text { through drip } \\
\text { (lit) }\end{array}$ & $\begin{array}{c}\text { Percent of crop } \\
\text { water requirement } \\
\text { supplied through } \\
\text { irrigation } \mathbf{( \% )}\end{array}$ \\
\hline Cucumber & 20 & 24 & 4800 & 686.4 & 14.30 \\
\hline Capsicum & $25-40$ & 48 & $9200-12000$ & 1830.2 & $19.89-15.25$ \\
\hline Coriander leaf & $5-10$ & 24 & $1200-2400$ & 232.0 & $19.33-9.67$ \\
\hline Spinach Beet & $5-10$ & 24 & $1200-2400$ & 225.6 & $18.80-9.40$ \\
\hline Cauliflower & $15-30$ & 48 & $7200-14400$ & 0.0 & 0 \\
\hline
\end{tabular}

This can be very encouraging for the promotion of organic farming in the polyhouses. Water management in the polyhouses is also a critical factor as poor water management can lead to crop water stress, reduced yield, increased risk pest and disease, and higher cost of cultivation. Regular monitoring of soil moisture and efficient application of irrigation water through drip irrigation was found to be beneficial. The cost of irrigation for all the crops were low. The majority of crop water requirement was met up from the residual soil moisture.

Due to presence of polyethylene sheets as cladding material, the evaporation loss from the soil was very low and therefore sufficient residual moisture was available to the crops. The amount of residual moisture depends on climate, crop season and rainfall. Crop like cauliflower could be grown fully based on residual moisture with no requirement of supplemental irrigation. Table 6 clearly shows that the percent of water requirement supplied through irrigation for different crops were low in the poly-houses ( $0 \%$ to $19.89 \%$ ).

In both the piloted sites the outcome of the research trial and farmers' response towards adoption of small-scale poly-house farming was encouraging. The study clearly demonstrated that low-cost poly-houses constructed using locally available construction materials can be a feasible option 
to the small and marginal farming community of the region.

The initial investment of the demonstrated technology is quite low and thus easily affordable to the farmers having low investment capacity. Protected cultivation of off-season vegetable crops has been identified as a remunerative agro-enterprise. However, profitability largely depended on proper choice of crop and their growing season should ensure good market price as well as demand. The quality of off-season vegetables grown in the poly-houses was good. Pest and disease problems were very rare.

Efficient water management strategies were found to be a critical factor in the poly-house farming practice. Due to low evaporation rate in the poly-houses, the major crop water requirement was met from residual soil moisture. In general irrigation requirement for off-season production of vegetables was quite low. Therefore, the drip irrigation system was used occasionally for some of the crops. Therefore, considering the observed regional trend, the initial investment of the poly-house farming could potentially be further reduced by considering drip irrigation system as a dispensable option.

\section{Acknowledgements}

This research work was financially supported by the Australian Centre for International Agricultural Research (ACIAR). The authors are thankful to Dr. Robyn Johnston, Research Program Manager for Water and Climate (ACIAR) and Mr. Erik Schmidt, Project Leader, for their support and valuable inputs.

\section{References}

Agrawal, N., Mehta, N., Sharma, H.G., Dixit, A. and Dubey, P. 2003. Cultivation of colecrops under protected environment.
Karnataka Journal of Agricultural Science. 16(2): 332-334.

Dhaliwal, M.S., Sharma, S.P., Jindal, S.K., Dhaliwal, L.K. and Gaikwad, A.K. 2017. Growth and yield of bell pepper as influenced by growing environment, mulch and planting date. Journal of Crop Improvement. 31(6): 830-846.

Kaddi, G., Tomar, B.S., Singh, B. and Kumar, S. 2014. Effect of growing conditions on seed yield and quality of cucumber (Cucumis sativus) hybrid.Indian Journal of Agricultural Sciences.84(5): 624-627.

Kuswardhani, N., Soni, P. and Shivakoti, G.P. 2014. Development protected cultivation in horticulture product: feasibility analysis in West Java province. International Journal on advanced science engineering information technology. 4(5): 66-70.

Lal, G., Mehta, R.S., Singh, R., Kakani, R.K., Meena, N.K. and Maheria, S.P. 2016. Effects of nitrogen levels on plant growth and leaf yield of off season coriander under shade nets. International Journal of Seed Spices.6(2):46-49.

Maitra, S.and De, L.C.2016. Protected cultivation of medicinal plants. In: Protected cultivation of ornamental plants. (Ed.) De, L. C. Aavishkar Publishers, Distributors. Jaipur, India. pp. 316-327.

Mishra, G.P., Singh, N., Kumar, H. and Singh, S.B. 2010. Protected cultivation for food and nutritional security at Ladakh. Defence Science Journal.61(2):219-225.

Negi, V.S., Maikhuri R.K., Rawat L.S. and Parshwan, D. 2013. Protected cultivation as an option of livelihood in mountain region of central Himalaya, India. International Journal of Sustainable Development \& World Ecology. 20(5): 416-425.

Singh, B. 2014. Protected cultivation of 
horticultural crops in India: Challenges and opportunities. Agrotechnol, $3^{\text {rd }}$ International Conference on Agriculture \& Horticulture, October 2729, 2014, Hyderabad International Convention Centre, India. 2(4):51.

Singh, B. and Hasan, M. 2011. Low pressure drip irrigation system: A success story (In Hindi). Agriculture Extension
Review. 21(2): 11-12.

Singh, B. and Sirohi, N.P.S. 2006. Protected cultivation of vegetables in India: problems and future prospects. ActaHorticulturae. 710(1):355-358.

Spehia, R.S. 2015. Status and impact of protected cultivation in Himachal Pradesh, India. Current Science. 108(12): 2254-2257.

\section{How to cite this article:}

Soumen Maitra, Biplab Mitra, Rupak Sarkar, Ranjit Chatterjee, Surajit Khalko and Om Prakash Chaturvedi. 2020. Small Scale Protected Cultivation for Off-season Vegetables: A Promising Option for Terai Farmers towards Income Generation. Int.J.Curr.Microbiol.App.Sci. 9(04): 972-980. doi: https://doi.org/10.20546/ijcmas.2020.904.116 